\title{
Chapter 17 \\ The Impact of Dutch Mathematics Education on Danish Mathematics Education
}

\author{
Mogens Niss
}

\begin{abstract}
Hans Freudenthal-in his capacity as a mathematician as well as a very articulate and thoughtful mathematics educator, as an international 'politician' of mathematics education, as the founder of Educational Studies in Mathematics, as a prolific writer, as an organiser of meetings and conferences-exerted quite an influence on Danish mathematics education from the late 1960s onwards. The Dutch mathematics education tradition thus founded always received close attention from the Danish mathematics education community. In this chapter, I outline and discuss the nature of this influence and I attempt to provide an explanation of why this tradition has resonated so well with implicit and explicit movements in Denmark.
\end{abstract}

Keywords Freudenthal · Freudenthal Institute $\cdot$ Guided re-invention • Mathematical modelling $\cdot$ PISA $\cdot$ Realistic Mathematics Education

\subsection{Introduction}

For centuries, the relationship between the Netherlands and Denmark has been one of mutual sympathy as well as of cultural and commercial exchange. We both are small, flat and democratic countries without strong formal hierarchies. And we have never been at war with one another. Our languages are part of the same sub-Germanic family, which friendly foreigners are kind enough to label throat diseases.

When it comes to mathematics and mathematics education, historical links are not of an old age, though. However, when Hans Freudenthal (of the University of Utrecht) took office in 1967 as the President of ICMI (the International Commission on Mathematical Instruction), later (in 1969) created the ICMEs (the International Congresses of Mathematical Education), and established the journal Educational Studies in Mathematics in 1968, the Netherlands strongly manifested itself in the international limelight and caught the attention of Danish mathematics educators.

\footnotetext{
M. Niss $(\bowtie)$

INM-Department of Science and Environment, Roskilde University, Roskilde, Denmark

e-mail: mn@ruc.dk 
This interest may in some respects be seen as somewhat surprising. The reason is that the set theory based so-called 'New Math' (or 'Modern Mathematics') movement that gained momentum in some parts and quarters of the world in the years 1955-1975, officially had Denmark as an enthusiastic member, whereas Freudenthal was quite a bit of a sceptic, to put it mildly, certainly much more so than leading Danish mathematicians and mathematics educators, above all Svend Bundgaard of the University of Aarhus and Bent Christiansen of the then Royal Danish School of Education. The brief biography of Freudenthal on the home page of the Freudenthal Institute leaves no doubt of Freudenthal's viewpoint and influence when it states: "Single-handedly Freudenthal saved Dutch education from the American teaching method of New Math, which was introduced in many countries from 1960 onwards". An indication of Freudenthal's scepticism can be found in an ICMI symposium on the teaching of geometry in secondary school that was hosted by the University of Aarhus in 1960, at which Freudenthal and a leading member of the Bourbaki group and New Math advocate Jean Dieudonné of France-two intellectuals who shared a weakness for polemic — engaged in no less than a quarrel.

Freudenthal (Elementærafdeling, 1960, p. 46):

It is dangerous with too radical changes. We don't obtain anything by introducing too much too early without thinking about the psychological and pedagogical problem.

Dieudonné (Elementærafdeling, 1960, p. 46):

There are many psychological difficulties; but we don't get anywhere if we are too cautious. There must come a change.

Freudenthal (Elementærafdeling, 1960, p. 47):

Much harm could be done by introducing new subjects in the school if the teachers don't know these subjects. Then it is better to wait until students reach university. It is more important to abandon obsolete subjects than to introduce new ones.

Freudenthal (Elementærafdeling, 1960, p. 104):

We cannot teach the pupils everything. There are certain psychological and pedagogical principles which must not be violated.

Dieudonné (Elementærafdeling, 1960, p. 104):

The important thing is to teach the students some good mathematics. The psychological considerations are of secondary importance. (La psychologie, je m'en fiche).

Over time, Bent Christiansen developed views which came rather close to Freudenthal's, which may well be a reflection of Christiansen's involvement as an ICMI Executive Committee Member and Vice-President, during the years 1975-1986.

\footnotetext{
${ }^{1}$ See www.fisme.science.nl/fisme/en/organisation/freudenthal.html. Accessed 7 March 2016 (the text can currently be found at http://www.mathunion.org/icmi/activities/awards/hans-freundenthalaward/).
} 


\subsection{Mathematics as an Educational Task and the Development of Realistic Mathematics Education}

To Danish mathematics educators, Dutch mathematics education was, for quite some time, synonymous with Hans Freudenthal, not the least so when he published his massive and impressive monograph Mathematics as an Educational Task (Freudenthal, 1973), which soon became a classic in the field and a must-read for the few people involved in research and development in mathematics education in Denmark in the 1970s and 1980s, but also for the more ambitious amongst the mathematics teacher educators in the teacher training colleges.

Freudenthal insisted on seeing mathematics not primarily as an established edifice of finished knowledge, which school may introduce and transmit to students and make them admire, but rather as a field of human activity, and not only that, also as a field of activity that is accessible to 'ordinary' students from the earliest grades. This view made a big impression on Danish mathematics education from the 1970s onwards, which was reflected in national syllabi and curriculum guidelines, in textbooks, and in actual teaching. Also, Freudenthal's emphasis on students' experiential sense-making in mathematics - by way of exploration and guided re-invention-as an essential component of learning exercised considerable and lasting influence on Danish mathematics educators.

In the context of the $\mathrm{IOWO}^{2}$ and its subsequent 'survivor research group' OW \& OC, ${ }^{3}$ existing until the establishment in 1991 of the Freudenthal Institute after Freudenthal's death in 1990, the signature programme of Dutch mathematics education, Realistic Mathematics Education (RME), was developed by Freudenthal himself and his collaborators and successors, including internationally well-known mathematics educators such as Jan de Lange, Adri Treffers, Leen Streefland, Koeno Gravemeijer, Marja van den Heuvel-Panhuizen and several others. Many Danish mathematics educators took - and take — great interest in this programme and quite a few have paid shorter or longer visits to the Freudenthal Institute and have established links with Dutch colleagues.

Why is it that RME has resonated with Danish mathematics educators to the extent it has? Let me offer a few elements of an explanation.

First of all, the Netherlands and Denmark seem to have a somewhat liberal, individualistic, independent and anti-authoritarian view of life and approach to education in common. This means that students' individual conceptions and experiences have to be respected and taken as points of departure for teaching and learning. Students - rather than being told what is the case, what to do and how to do it-have to see things for themselves, explore their environment and the world, make exper-

\footnotetext{
${ }^{2}$ Instituut voor Ontwikkeling van het Wiskundeonderwijs (Institute for the Development of Mathematics Education); IOWO as a part of Utrecht University was established by Freudenthal in 1971 and closed by the university in 1981 .

3 Onderzoek Wiskundeonderwijs \& Onderwijs Computercentrum (Mathematics Education Research and Educational Computer Centre).
} 
iments, try to figure out how things are related, produce independent reasoning to explain their deliberations, undertakings and findings so as to justify their work and its results. Of course, students need inspiration and stimuli by means of challenging tasks and subsequent guiding by competent teachers so as to ensure the process of guided re-invention. However, the teacher is perceived as a more experienced ally and supervisor rather than as an absolute authority. The individual student's thinking is not only to be taken seriously, but is considered interesting in its own right—as is illustrated so well in Freudenthal's accounts of his dialogues with his grandson Bastiaan.

What about the term 'realistic'? This may be a point where some divergence can be found between the Dutch and the Danish positions. In the Dutch position, 'real' and 'realistic' tend to refer to students' experiential or emotional worlds, not necessarily to reality in some domain of an objective external world. Thus, worlds of adventure, fantasy or games are considered real and realistic if they are so to the students in focus. Of course, this does not imply that objective external reality is excluded from being considered real and realistic, if only students perceive it as motivating and engaging to deal with. In contrast, the Danish position tends to emphasise the external objective reality of the surroundings in which students live, be it the surroundings constituted by family, friends, school, sports, leisure or holidays, be it in the civic or societal surroundings in the local, national or global community, or be it in other scholarly and scientific fields or areas of practice.

\subsubsection{Mathematical Modelling}

A related point of common interest in Dutch and Danish mathematics education - and yet another reason why RME has attracted attention in Denmark-is the notion and role of mathematical models and mathematical modelling. Once again, Freudenthal took an early initiative by involving himself in organising an international colloquium Why to Teach Mathematics as to Be Useful, held in Utrecht in 1967, by giving the opening address titled "Why to Teach Mathematics so as to Be Useful" at that symposium, and by publishing the talks of the symposium, including his own talk in the first volume of Educational Studies in Mathematics (Freudenthal, 1968). During the 1970s, 1980s and 1990s, both countries developed a strong interest in mathematical applications and mathematical modelling for educational purposes, especially at the upper secondary school level, and a fair amount of mutual inspiration and exchange of information, ideas and materials took place between educators from both countries.

As is well-known, the Dutch RME tradition distinguishes between two different sorts of mathematisation, horizontal and vertical mathematisation, a distinction introduced by Adri Treffers in his doctoral dissertation from 1978, later transformed into a book in English (Treffers, 1987). In horizontal mathematisation, an extramathematical situation or context is translated into some mathematical domain with the purpose of subjecting aspects of the situation or context to mathematical treatment and eventually inference making. This is the key process in what is usually-in 
the mathematical modelling literature-called mathematical modelling (see, e.g., Blum, Galbraith, Henn, \& Niss, 2007). In vertical mathematisation, a mathematical entity, situation or problem under consideration is transformed into another mathematical entity, situation or problem, typically belonging to a different area than did the original, with the purpose of utilising conceptualisations and approaches of the new area to deal with the transformed entity, situation or problem so as to obtain results pertaining to the original situation. It is worth noting that initially Freudenthal was sceptical towards the usefulness of this distinction, but ended up favouring it in his China Lectures (Freudenthal, 1991, p. 41).

This distinction, however, never gained a foothold in Danish mathematics education, primarily because mathematical modelling, including (horizontal) mathematisation, involving some extra-mathematical domain, is perceived as categorially very different from the internal mathematical transformations and processes involved in vertical mathematisation. One might speculate that the reason why, in the Netherlands, horizontal and vertical mathematisation are seen as two sides of the same coin might be that in the RME tradition reality, experience, human minds and mathematics are perceived as constituting a continuum, whereas there is a much more pronounced distinction between reality and mathematics, and between reality and the mind, in Danish mathematics education.

A key point in RME is Koeno Gravemeijer's notion of 'emergent mathematical modelling' (Gravemeijer, 1999, 2007), in which students' attempts at coming to grips with realistic situations (in the sense as it is conceived in RME) may lead them to (re-)invent concepts and relations of formal mathematics as well as to eventually engage in more full-fledged mathematical modelling. The transition from 'models of' to 'models for' is a pivotal idea in this approach that originates with Leen Streefland (1996, 2003). Put somewhat pointedly, this approach may be condensed into a goal stated as if it were a slogan 'modelling for the sake of mathematics (learning)'. The Danish position tends to put emphasis on the reverse goal, namely 'mathematics (learning) for the sake of modelling'. This means that modelling the extra-mathematical world existing outside students' minds is a primary goal in its own right. It goes without saying that there is no contradiction whatsoever between 'modelling for the sake of mathematics (learning)' and 'mathematics (learning) for the sake of modelling'. The difference rather lies in priorities and emphases. Moreover, a given activity may well lend itself to both goals, thus leaving the distinction a bit blurred in actual practice.

One platform for students' engagement in mathematical modelling of aspects of extra-mathematical domains is the A-lympiad, which is an annual modelling contest for students in the upper levels of secondary education in the Netherlands and elsewhere, organised for many years by the Freudenthal Institute, and currently being led by Ruud Stolwijk, in collaboration with colleagues in other European countries. The 'A' stands for the application-oriented curriculum in Dutch upper secondary mathematics, a curriculum which largely grew out of RME. Also, Danish schools have students who participate in this contest. 


\subsubsection{Integrating Research and Development}

A very significant aspect of RME in the Netherlands is that it integrates research and development work, in the sense that the implementation of developmental ideas is followed up and assessed by research and vice versa: research findings lead to further developmental ideas. It is no surprise that this approach has been generalised into one version of what might well be considered a meta research paradigm for (mathematics) education, of course a paradigm with a multitude of different ramifications, called 'design research'. Protagonists in this development are Koeno Gravemeijer, Paul Drijvers, Michiel Doorman, and others, oftentimes in close collaboration with Paul Cobb. These versions of design research have been an inspiration for several Danish mathematics educators as well.

\subsubsection{Criticism}

It is no secret that RME in the Netherlands has been met with criticism, sometimes fierce criticism, especially in recent years, from mathematicians and others who find the philosophy and the implementation of RME detrimental to mathematics teaching and learning, because they put too much emphasis on exploration and inductively oriented guided re-invention and too little emphasis on formal concept formation and mathematical deduction, thus tending to undermine the recruitment of students to 'serious' tertiary mathematics programmes. Presumably such criticism has also contributed to changing the structure, role and position of the Freudenthal Institute in relation to Utrecht University. Perhaps one might even speak about a sort of Math War in the Netherlands. Even if views do of course vary greatly across and within different quarters of mathematicians and mathematics educators in Denmark, we have not experienced anything like Math Wars, despite the fact that much Danish school mathematics has been markedly influenced by RME. However, in some respects similar divides may be emerging in Denmark, in particular because graphing and symbolic calculators and computers with dynamic geometry and CAS (computer algebra systems) programs tend to replace formal mathematical concept formation and reasoning as well as procedural skills, partly with (undue) reference to RME inspired views of mathematics.

\subsection{PISA}

It is widely known that when the Organisation for Economic Cooperation and Development (OECD) decided to launch the Programme for International Student Assessment (PISA) in the late 1990s and made mathematics one of the three domains of assessment, Jan de Lange of the Freudenthal Institute was appointed chair of the 
Mathematics Expert Group (MEG). The author of this chapter became one of the other members. The MEG provided the first definition ever of mathematical literacy, the crucial notion in the mathematics domain in PISA. The fact that Jan de Lange chaired the MEG was instrumental for the genesis and development of the spirit of PISA mathematics, both when it came to the design of the framework for the mathematics part of the assessment, and-perhaps even more so-when it came to the development of assessment items. This fact and the fact that one of the leading test developers throughout the years was another Dutchman, Kees Lagerwaard, left an unmistakably Dutch fingerprint on PISA mathematics from the very beginning, above all on the nature of the test items. This state of affairs was amplified by the involvement in the first PISA consortium of Cito, the Dutch national institute for educational measurement.

So, in many places around the world people tended to see PISA as dominated by a Dutch — or, to be more precise, an RME — perspective. This is evidently an important part of the truth because of the marked Dutch involvement in PISA mathematics, but it is not the whole truth, since all those involved in the MEG, myself included, were in full agreement about everything that was going on in mathematics. We saw PISA's undertakings with respect to mathematics as sound outlets of mathematical literacy at large rather than as a particularly Dutch project. As a matter of fact, a non-trivial part of the thinking and writing on PISA mathematics came from MEG members other than the chair.

Against this background, it is no surprise that PISA mathematics was well received amongst Danish mathematics educators, even though there is a general scepticism and criticism in Denmark about the very idea of international comparative studies such as PISA, and above all about the political (ab)uses of PISA country rankings. However, that scepticism pertains to the overall enterprise rather than to the mathematics component of PISA. Especially the (released) test items have generally been perceived as relevant and reasonable expressions of mathematical literacy.

\subsection{Concluding Remarks}

In this chapter I have tried to identify some significant points with respect to which Dutch mathematics education has - and has had-an impact on Danish mathematics education, in research and development as well as in practice. As is presumably evident, this impact is certainly non-negligible, even though there are also important differences between Dutch and Danish mathematics education. The influences identified mainly stem from Hans Freudenthal, the Freudenthal Institute and from RME. It should not go unnoticed, however, that there are also other links between Dutch and Danish mathematics education, for example, through Jan van Maanen, whose work on the role of the history of mathematics in mathematics education has inspired more than one Danish mathematics educator. 
It remains to be seen whether the fundamental changes of the Freudenthal Institute will also fundamentally undermine the contributions of Dutch mathematics education to mathematics education in the world and in Denmark. We certainly hope not.

\section{References}

Blum, W., Galbraith, P. L., Henn, H.-W., \& Niss, M. (Eds.). (2007). Modelling and applications in mathematics education: The 14th ICMI Study. Dordrecht, New York, Heidelberg: Springer.

Elementærafdeling. (1960). Lectures on modern teaching of geometry and related topics held at the ICMI-seminar in Aarhus, May 30 to June 2, 1960. Elementærafdeling nr. 7 AaU, Matematisk Institut. Aarhus, Denmark: Matematisk Institut.

Freudenthal, H. (1968). Why teach mathematics so as to be useful. Educational Studies in Mathematics, 1, 3-8.

Freudenthal, H. (1973). Mathematics as an educational task. Dordrecht, the Netherlands: D. Reidel Publishing Company.

Freudenthal, H. (1991). Revisiting mathematics education-China lectures . Dordrecht, the Netherlands: Kluwer Academic Publishers.

Gravemeijer, K. (1999). How emergent models may foster the constitution of formal mathematics. Mathematical Thinking and Learning, 1(2), 155-177.

Gravemeijer, K. (2007). Emergent modelling as a precursor to mathematical modelling. In W. Blum, P. L. Galbraith, H.-W. Henn, \& M. Niss (Eds.), Modelling and applications in mathematics education: The 14th ICMI Study (pp. 37-144). Dordrecht, New York, Heidelberg: Springer.

Streefland, L. (1996). Learning from history for teaching in the future. Regular lecture held at the ICME-8 in Sevilla, Spain.

Streefland, L. (2003). Learning from history for teaching in the future. Educational Studies in Mathematics, 54, 37-62.

Treffers, A. (1987). Three dimensions: A model of goals and theory description in mathematics education-The Wiskobas project . Dordrecht, the Netherlands: Kluwer Academic Publishers.

Open Access This chapter is distributed under the terms of the Creative Commons Attribution 4.0 International License (http://creativecommons.org/licenses/by/4.0/), which permits use, duplication, adaptation, distribution and reproduction in any medium or format, as long as you give appropriate credit to the original author(s) and the source, a link is provided to the Creative Commons license and any changes made are indicated.

The images or other third party material in this chapter are included in the work's Creative Commons license, unless indicated otherwise in the credit line; if such material is not included in the work's Creative Commons license and the respective action is not permitted by statutory regulation, users will need to obtain permission from the license holder to duplicate, adapt or reproduce the material.

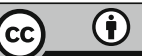

